UDC 666.112 .7

Yu.S. Hordieiev, A.A. Amelina

\title{
GLASS FORMATION AND PROPERTIES OF GLASSES IN THE SYSTEM $\mathrm{SrO}-\mathrm{B}_{2} \mathrm{O}_{3}-\mathrm{SiO}_{2}-\mathrm{xAl}_{2} \mathrm{O}_{3}(\mathrm{x}=0 ; 10 \mathrm{MOL} . \%)$
}

\author{
Ukrainian State University of Chemical Technology, Dnipro, Ukraine
}

\begin{abstract}
The paper shows the prospects of the system $\mathrm{SrO}-\mathrm{Al}_{2} \mathrm{O}_{3}-\mathrm{B}_{2} \mathrm{O}_{3}-\mathrm{SiO}_{2}$ as a basis for the synthesis of new vitreous and glass-ceramic materials, which are widely used as electrical insulated and high-temperature coatings, for sealing of solid oxide fuel cells, and in the production of heat resistant materials. We experimentally established the conditions of glass formation, regions of glass-forming melts and properties of glasses, the chemical composition of which is limited by the following content of components (mol.\%): $\mathrm{SrO}$ $30-80, \mathrm{~B}_{2} \mathrm{O}_{3} 10-60, \mathrm{SiO}_{2} 10-60$, and $\mathrm{Al}_{2} \mathrm{O}_{3} 0-10$. It is shown that during the synthesis of glasses in the corundum crucible at the temperature of $1350^{\circ} \mathrm{C}$ the region of glass formation in the system $\mathrm{SrO}-\mathrm{B}_{2} \mathrm{O}_{3}-\mathrm{SiO}_{2}$ is limited by the following content of components (mol.\%): $\mathrm{SrO} 30-60, \mathrm{~B}_{2} \mathrm{O}_{3} 10-60$, and $\mathrm{SiO}_{2}$ 10-50. It is found that the introduction of $\mathrm{Al}_{2} \mathrm{O}_{3}$ to the composition of these glasses expands the region of glass formation towards increase of the $\mathrm{SiO}_{2}$ content in the glass up to $60 \mathrm{~mol} \%$. Experimentally determined values of glass properties are within the following limits: coefficient of linear thermal expansion (67118) $\cdot 10^{-7} \mathrm{~K}^{-1}$; glass transition temperature $570-660^{\circ} \mathrm{C}$; dilatometric softening point $580-$ $700^{\circ} \mathrm{C}$; and density $2.62-3.71 \mathrm{~g} \mathrm{~cm}^{-3}$. The established patterns of influence of the components and conditions of glass formation on the physical and chemical characteristics of glasses may serve as an experimental basis for designing of new materials with a complex of specified properties, which allows solving the problems of their practical use.
\end{abstract}

Keywords: glass, glass formation, thermal expansion, glass transition temperature, volume resistivity.

DOI: $10.32434 / 0321-4095-2021-138-5-43-49$

\section{Introduction}

One of the urgent and highly demanded, from a practical standpoint, issues of modern materials science is the development of scientific and technological bases for the creation of new glassceramic and vitreous materials based on alkali-free borosilicate systems with a complex of specified properties.

The system $\mathrm{SrO}-\mathrm{Al}_{2} \mathrm{O}_{3}-\mathrm{B}_{2} \mathrm{O}_{3}-\mathrm{SiO}_{2}$ is one of the promising glass-forming systems for the synthesis of various technologically demanded materials, from nonlinear optical and laser media [1,2] to sealants [3] and bioactive materials [4,5]. These materials have a number of valuable properties, e.g. chemical stability, heat resistance, biocompatibility, impermeability to gases and water and protection against ionizing radiation [4-6]. Aluminum oxide plays an important role in this system. At moderate concentrations from 0 to $10 \mathrm{~mol} \%$, the addition of
$\mathrm{Al}_{2} \mathrm{O}_{3}$ counteracts crystallization of glass, reducing the liquidus temperature of the system and rate of the crystal growth [7]. At low concentrations, aluminum oxide, obviously, serves as a glass-forming component [8,9], and at higher concentrations it acts as a glass network modifier [7,10]. Performing this dual role, $\mathrm{Al}_{2} \mathrm{O}_{3}$ can both inhibit and enhance the crystallization of glass [10]. Aluminum oxide also has a positive effect on the electrical insulation properties of alkali-free borosilicate systems. With an increase in the content of $\mathrm{Al}_{2} \mathrm{O}_{3}$ due to $\mathrm{SiO}_{2}$, the electrical resistance of glasses grows, while dielectric losses decrease [7-9]. However, there is no sufficient information in the literature on the conditions of glass formation and physicochemical properties of the abovementioned glasses, which could serve as an experimental base for designing of new materials with a complex of specified properties.

In view of this, the purpose of this study is to

(C) Yu.S. Hordieiev, A.A. Amelina, 2021

Glass formation and properties of glasses in the system $\mathrm{SrO}-\mathrm{B}_{2} \mathrm{O}_{3}-\mathrm{SiO}_{2}-x \mathrm{Al}_{2} \mathrm{O}_{3}(x=0 ; 10 \mathrm{~mol} . \%)$ 
establish the conditions of glass formation and relationship between the properties of oxide glasses and their chemical composition for the systems that are limited by the following content of components (mol.\%): $\mathrm{SrO} 30-80, \mathrm{~B}_{2} \mathrm{O}_{3} 10-60, \mathrm{SiO}_{2} 10-60$, and $\mathrm{Al}_{2} \mathrm{O}_{3} 0-10$.

\section{Materials and methods}

Finely ground quartz sand and chemical reagents of the laboratory reagent and analytical reagent grade (boric acid, strontium carbonate, alumina) were used to prepare the mixtures of experimental glasses. Melting of glasses was carried out in the corundum crucibles with the volume of $100 \mathrm{ml}$ in the electric furnace with silicon carbide heaters at the temperature of $1350^{\circ} \mathrm{C}$ during 60 minutes. Samples of glasses were made by the method of glass melt casting into steel molds followed by annealing in the muffle furnace at the temperature of $500^{\circ} \mathrm{C}$. Then the properties of the prepared glasses were determined.

Melting characteristics of the experimental glasses were studied in the corundum crucibles with the volume of $10 \mathrm{ml}$. Crucibles with the mixture were placed in the furnace heated to $1350^{\circ} \mathrm{C}$ and held for 60 minutes. At the end of the holding time, the crucibles were removed from the furnace and cooled in the air.

The properties of glasses were determined by standard methods: the density (d) of glasses was determined by hydrostatic weighing in accordance with GOST 9553-74; dilatometric studies of the coefficient of linear thermal expansion (CTE) were performed in the temperature range of $20-400^{\circ} \mathrm{C}$; dilatometric softening point $\left(\mathrm{t}_{\mathrm{d}}\right)$ and glass transition temperature $\left(\mathrm{t}_{\mathrm{g}}\right)$ were found in accordance with GOST 10978-2014.

Volume resistivity of glasses was measured by E6-13A teraohmmeter with the use of the electrode thermocell (graphite electrodes).

Crystallization ability of glass powders was examined by the method of differential thermal analysis on the derivatograph Q-1500D in the temperature range of 20 to $1000^{\circ} \mathrm{C}$ at the heating rate of $10^{\circ} \mathrm{C} / \mathrm{min}$. Alumina oxide fired at the temperature of $1450^{\circ} \mathrm{C}$ was used as a reference.

$\mathrm{X}$-ray phase analysis of glasses was carried out on a diffractometer DRON-3M in Co- $\mathrm{K}_{\alpha}$ radiation. To identify crystalline phases, $\mathrm{X}$-ray card index of ASTM was used.

\section{Results and discussion}

When studying glasses in the system $\mathrm{SrO}-\mathrm{Al}_{2} \mathrm{O}_{3}-\mathrm{B}_{2} \mathrm{O}_{3}-\mathrm{SiO}_{2}$, we took into account the results of previous studies of the conditions of glass formation in the system $\mathrm{BaO}-\mathrm{Al}_{2} \mathrm{O}_{3}-\mathrm{B}_{2} \mathrm{O}_{3}-\mathrm{SiO}_{2}$ [8]. The introduction of $\mathrm{Al}_{2} \mathrm{O}_{3}$ (up to $10 \mathrm{~mol} . \%$ ) into the composition of these glasses contributed to the reduction of crystallization ability of glass melts and expansion of the region of glass formation towards an increase of $\mathrm{BaO}$ content in the glass to $60 \mathrm{~mol} . \%$.

The synthesis of glasses and study of glass formation conditions were carried out in the cross sections of the system $\mathrm{SrO}-\mathrm{B}_{2} \mathrm{O}_{3}-\mathrm{SiO}_{2}$ and $\mathrm{SrO}-\mathrm{B}_{2} \mathrm{O}_{3}-\mathrm{SiO}_{2}-10 \mathrm{Al}_{2} \mathrm{O}_{3}$ with the following content of basic components (mol.\%): $\mathrm{SrO} 30-80, \mathrm{~B}_{2} \mathrm{O}_{3} 10-$ 60 , and $\mathrm{SiO}_{2}$ 10-60. As a result of the study of the melting properties of experimental glasses, boundaries of glass formation at the temperature of $1350^{\circ} \mathrm{C}$ and regions of glasses which were visually clear and also those crystallized were plotted on the diagram of the system $\mathrm{SrO}-\mathrm{B}_{2} \mathrm{O}_{3}-\mathrm{SiO}_{2}-\mathrm{xAl}_{2} \mathrm{O}_{3}$ (Fig. 1).

Experimental data of glass formation conditions show that the system under consideration is characterized by a wide range of visually transparent glasses as well as glasses resistant to crystallization in the production, including the compositions with a high content of SrO. Under assumed temperature

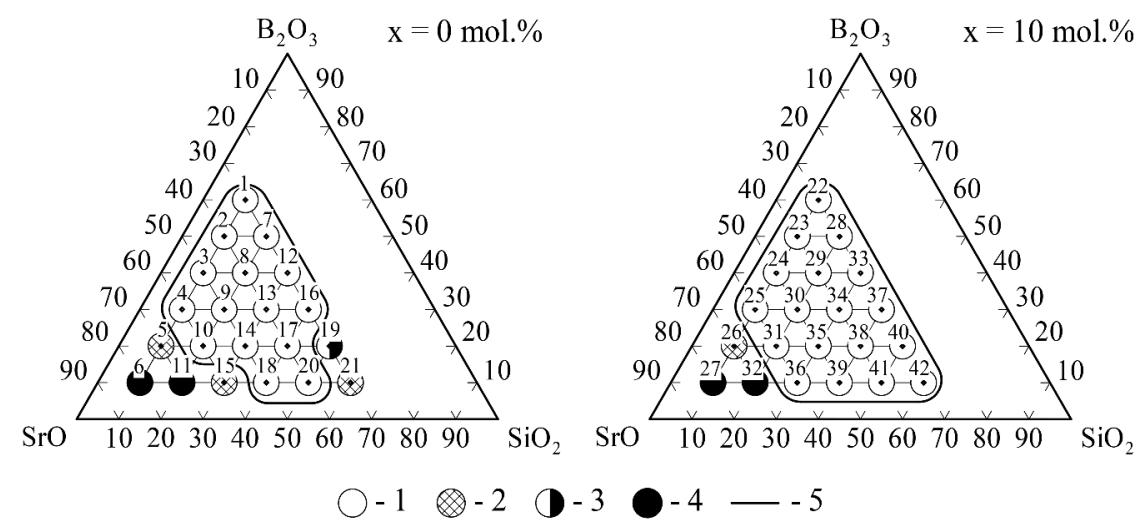

Fig. 1. Chemical compositions of experimental glasses and glass formation in the system $\mathrm{SrO}-\mathrm{B}_{2} \mathrm{O}_{3}-\mathrm{SiO}_{2}-\mathrm{xAl}_{2} \mathrm{O}_{3}$ : $1-$ clear glass; 2 - crystallization; 3 - liquation; 4 - sinter; 5 - border of glass-forming region 
and time conditions, the melting of mixture components with the formation of homogeneous glass-forming melts stops at the $\mathrm{SrO}$ content of $60 \mathrm{~mol} . \%$.

According to data reported by Tyurnina et al. [11], the glass of the system $\mathrm{SrO}-\mathrm{B}_{2} \mathrm{O}_{3}-\mathrm{SiO}_{2}$ synthesized in the platinum crucible is formed at the $\mathrm{SrO}$ content from 30 to $50 \mathrm{~mol} . \%$. At the same time, in case of synthesis in corundum crucibles, we obtained the glass with $\mathrm{SrO}$ content of up to 60 mol.\%. Expansion of the glass formation region in the ternary system $\mathrm{SrO}-\mathrm{B}_{2} \mathrm{O}_{3}-\mathrm{SiO}_{2}$ under study in case of its synthesis in corundum crucibles is caused by their corrosion, resulting in the diffusion of a part of $\mathrm{Al}_{2} \mathrm{O}_{3}$ from the crucible material to the glass melt. The above contributes to the formation of glass at high content of $\mathrm{SrO}$, where $\mathrm{Al}_{2} \mathrm{O}_{3}$, apparently, acts as glass-forming component. Aggressiveness of the mixture and glass melt in relation to the material of corundum crucibles has been previously established in the studies of glasses in the system $\mathrm{RO}-\mathrm{B}_{2} \mathrm{O}_{3}-\mathrm{SiO}_{2}$ $(\mathrm{R}=\mathrm{Ba}$; $\mathrm{Ca})[8,12]$.

When comparing the glass-forming regions in cross sections of the system under consideration, we can draw the conclusion that the addition of $\mathrm{Al}_{2} \mathrm{O}_{3}$ expands the range of visually clear glasses, as well as glass resistant to crystallization in the production,

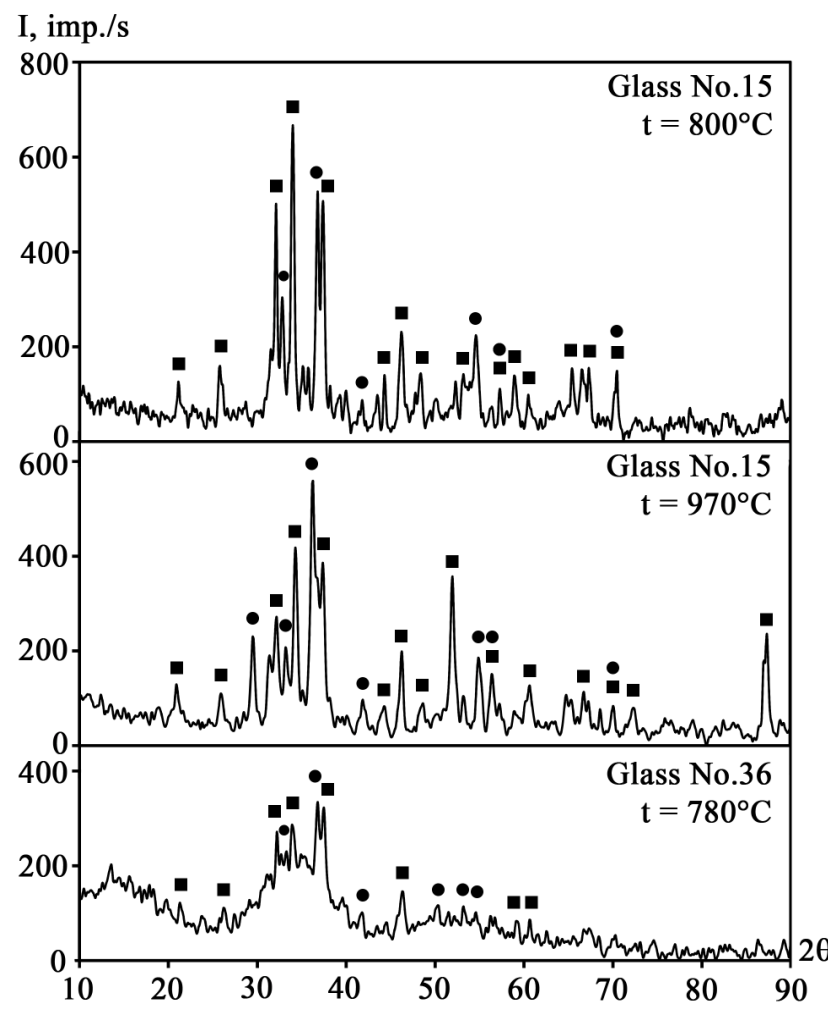

towards an increase in the $\mathrm{SrO}$ and $\mathrm{SiO}_{2}$ content to $60 \mathrm{~mol} . \%$. Additional introduction of $10 \mathrm{~mol} . \%$ of $\mathrm{Al}_{2} \mathrm{O}_{3}$ into the compositions of glasses No. 4 and No. 15 (Fig. 2, a and Fig. 2,c) reduces the crystallization ability of the melts of these glasses, as

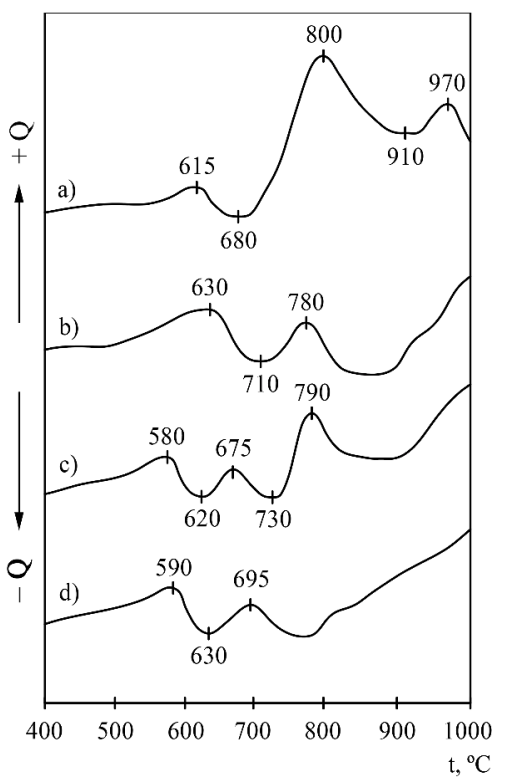

Fig. 2. DTA curves of glass powders: $a-$ No. $15 ; \mathrm{b}-$ No. 36 ; c - No. 4; d - No. 25

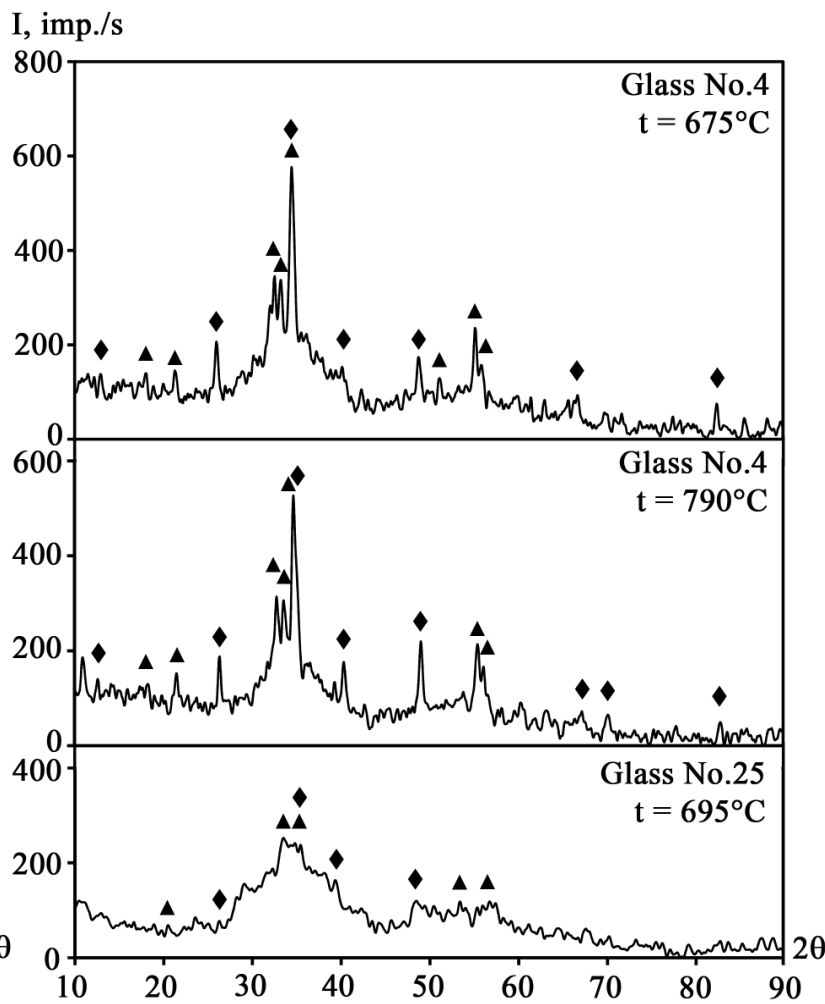

Fig. 3. X-ray patterns of powders of glass in the system $\mathrm{SrO}-\mathrm{Al}_{2} \mathrm{O}_{3}-\mathrm{B}_{2} \mathrm{O}_{3}-\mathrm{SiO}_{2}$ after heat treatment during 2 hours at different temperatures of crystallization: $-\mathrm{Sr}_{2} \mathrm{Al}_{2} \mathrm{SiO}_{7} ; \mathbf{-}-\mathrm{Sr}_{2} \mathrm{SiO}_{4} ; \mathbf{\Delta}-\mathrm{Sr}_{2} \mathrm{~B}_{2} \mathrm{O}_{5} ;--\mathrm{SrAl}_{2} \mathrm{Si}_{2} \mathrm{O}_{8}$ 
evidenced by a decrease in the intensity of the relevant exothermic effects on the DTA curves of powders of glasses No. 25 and No. 36 (Fig. 2,b and Fig. 2,d).

Diffusion of $\mathrm{Al}_{2} \mathrm{O}_{3}$ from the crucible material into the glass melt owing to their active interaction is confirmed by the results of X-ray phase analysis of glasses No. 4 and No. 15 (Fig. 3), mixtures of which did not contain $\mathrm{Al}_{2} \mathrm{O}_{3}$ at all. According to the data of $\mathrm{X}$-ray phase analysis, strontium silicate $\left(\mathrm{Sr}_{2} \mathrm{SiO}_{4}\right)$ and $\mathrm{Sr}$-gehlenite $\left(\mathrm{Sr}_{2} \mathrm{Al}_{2} \mathrm{SiO}_{7}\right)$ can be identified as the main crystalline phases during heat treatment of glass No. 15. Position of the main diffraction maximums on X-ray patterns of the glass powder No. 4 indicates that the main crystalline phases formed during heat treatment of this glass are strontium borate $\left(\mathrm{Sr}_{2} \mathrm{~B}_{2} \mathrm{O}_{5}\right)$ and $\mathrm{Sr}$-anortite
$\left(\mathrm{SrAl}_{2} \mathrm{Si}_{2} \mathrm{O}_{8}\right)$. Addition of $10 \mathrm{~mol} . \%$ of $\mathrm{Al}_{2} \mathrm{O}_{3}$ to the composition of glasses No. 4 and No. 15 reduces the amount of the crystalline phase, which is confirmed by a decrease in the intensity of diffraction maxima on X-ray patterns of powders of glasses No. 25 and No. 36 (Fig. 3).

Further study of the physical and chemical properties of glasses was carried out on the compositions of visually clear glasses and glasses resistant to crystallization in the production (Fig. 1). Experimentally established vales of properties of experimental glasses are given in Table 1 .

Data analysis shows that depending on the chemical composition of experimental glasses their properties vary over the wide range: coefficient of linear thermal expansion of $(67-118) \cdot 10^{-7} \mathrm{~K}^{-1}$; glass

Physical and chemical properties of glasses

Table 1

\begin{tabular}{|c|c|c|c|c|c|}
\hline Glass No. & CTE, $\alpha \cdot 10^{7}, \mathrm{~K}^{-1}$ & $\mathrm{t}_{\mathrm{g}},{ }^{0} \mathrm{C}$ & $\mathrm{t}_{\mathrm{d}},{ }^{0} \mathrm{C}$ & $\begin{array}{c}\lg \rho, \mathrm{Ohm} \cdot \mathrm{cm} \\
\left(150^{\circ} \mathrm{C}\right)\end{array}$ & Density, $\mathrm{d}, \mathrm{g} / \mathrm{cm}^{3}$ \\
\hline 1 & 69 & 570 & 580 & 12.21 & 2.82 \\
\hline 2 & 82 & 580 & 600 & 12.39 & 3.10 \\
\hline 3 & 92 & 580 & 610 & 12.86 & 3.30 \\
\hline 4 & 107 & 590 & 620 & 13.54 & 3.46 \\
\hline 7 & 74 & 600 & 610 & 12.25 & 3.00 \\
\hline 8 & 86 & 610 & 620 & 12.35 & 3.19 \\
\hline 9 & 97 & 610 & 640 & 12.85 & 3.39 \\
\hline 10 & 118 & 620 & 650 & 13.26 & 3.68 \\
\hline 12 & 75 & 600 & 630 & 12.33 & 3.05 \\
\hline 13 & 88 & 620 & 640 & 12.57 & 3.22 \\
\hline 14 & 103 & 630 & 660 & 13.11 & 3.46 \\
\hline 16 & 75 & 640 & 670 & 12.42 & 3.09 \\
\hline 17 & 96 & 650 & 670 & 13.49 & 3.35 \\
\hline 18 & 105 & 640 & 680 & 13.49 & 3.55 \\
\hline 20 & 94 & 650 & 690 & 13.38 & 3.40 \\
\hline 22 & 67 & 570 & 600 & 12.58 & 2.62 \\
\hline 23 & 77 & 580 & 610 & 12.72 & 3.02 \\
\hline 24 & 87 & 580 & 620 & 13.29 & 3.24 \\
\hline 25 & 101 & 590 & 630 & 14.49 & 3.39 \\
\hline 28 & 67 & 600 & 630 & 12.62 & 2.95 \\
\hline 29 & 78 & 605 & 630 & 13.00 & 3.10 \\
\hline 30 & 94 & 610 & 640 & 13.52 & 3.28 \\
\hline 31 & 106 & 620 & 655 & 14.00 & 3.48 \\
\hline 33 & 68 & 615 & 635 & 12.70 & 2.93 \\
\hline 34 & 81 & 620 & 645 & 13.18 & 3.20 \\
\hline 35 & 101 & 620 & 650 & 13.45 & 3.42 \\
\hline 36 & 109 & 615 & 670 & 14.25 & 3.71 \\
\hline 37 & 68 & 620 & 640 & 12.75 & 2.96 \\
\hline 38 & 86 & 630 & 650 & 12.85 & 3.26 \\
\hline 39 & 101 & 640 & 680 & 14.03 & 3.50 \\
\hline 40 & 70 & 640 & 690 & 13.00 & 3.05 \\
\hline 41 & 88 & 650 & 690 & 13.91 & 3.32 \\
\hline 42 & 74 & 660 & 700 & 13.74 & 3.06 \\
\hline
\end{tabular}


transition temperature of $570-660^{\circ} \mathrm{C}$; dilatometric softening point of $580-700^{\circ} \mathrm{C}$; and density of $2.62-$ $3.71 \mathrm{~g} / \mathrm{cm}^{3}$. The volume resistivity of experimental glasses at the temperature of $150^{\circ} \mathrm{C}$ is within $10^{12-}$ $10^{14} \mathrm{Ohm} \cdot \mathrm{cm}$, indicating their high electrical insulation properties.

The relationship between the properties of multicomponent glasses and their composition in glass chemistry and technology is expressed with the use of the additive formula:

$$
\mathrm{V}=\mathrm{S}\left(\mathrm{v}_{\mathrm{i}} \cdot \mathrm{x}_{\mathrm{i}}\right) / 100 \text {, }
$$

where $\mathrm{V}$ is the calculated value of glass properties; $\mathrm{v}_{\mathrm{i}}$ are the additive coefficients (partial contributions of oxides to the value of glass properties); $\mathrm{x}_{\mathrm{i}}$ are the contents of oxides in the glass, mol.\%.

This additive formula represents a compact form of the generalized and quantitative description of the patterns of change in glass properties depending on its composition. In this context, additive coefficients in the equations for calculating the values of properties of the experimental glasses (Table 2) were determined in this study by the multiple correlation method. Accuracy of the calculation of these properties was evaluated by the value of the multiple correlation coefficient (R) and by comparison of the residual dispersion $\mathrm{S}^{2}$ res with the dispersion relative to the average value of the experimental properties $\mathrm{S}_{\mathrm{y}}^{2}[13,14]$. As indicated by the data of Table 2, $\mathrm{S}_{\text {res }}^{2}$ is much less than $\mathrm{S}_{\mathrm{y}}^{2}$, so we can assume that Eq. (1) gives a reasonable approximation for the experimental data of Table 2 .

It can be seen that general tendencies in the change of properties of glasses of the system $\mathrm{SrO}-\mathrm{Al}_{2} \mathrm{O}_{3}-\mathrm{B}_{2} \mathrm{O}_{3}-\mathrm{SiO}_{2}$ are maintained, as a whole, for the similar properties glasses of the system $\mathrm{BaO}-\mathrm{Al}_{2} \mathrm{O}_{3}-\mathrm{B}_{2} \mathrm{O}_{3}-\mathrm{SiO}_{2}$ as well [8]. Silicon dioxide makes the largest partial contribution to the values of glass transition temperature and dilatometric softening point. This fact should be taken into account when choosing the compositions of glasses for the protective coatings, as an increase in $\mathrm{SiO}_{2}$ content will lead to an increase in the temperature of formation of the protective coatings. Replacement of $\mathrm{SiO}_{2}$ by $\mathrm{B}_{2} \mathrm{O}_{3}$ causes no significant changes in the CTE values and at the same time contributes to the sharp decrease in the glass transition temperature and dilatometric softening point of experimental glasses. The latter is due to the fact that $\mathrm{B}_{2} \mathrm{O}_{3}$ reduces the glass viscosity.

The largest partial contribution to the values of the coefficient of linear thermal expansion and density of glasses is made by $\mathrm{SrO}$. An increase in the $\mathrm{SrO}$ content in the glass due to $\mathrm{SiO}_{2}$ promotes reduction of glass transition temperature and dilatometric softening point of a glass. It is explained by low degree of covalence bond $\mathrm{Sr}-\mathrm{O}$ and large radius of $\mathrm{Sr}^{2+}(1.21 \AA)$ [7].

The introduction of $\mathrm{Al}_{2} \mathrm{O}_{3}$ into the composition of the system $\mathrm{SrO}-\mathrm{B}_{2} \mathrm{O}_{3}-\mathrm{SiO}_{2}$ contributes to strengthening of the glass lattice, which in turn assists in reduction of crystallization ability of glass melts, lowering of the coefficient of linear thermal expansion and increasing the volume resistivity of the experimental glasses.

\section{Conclusions}

We have experimentally established the conditions of glass formation, regions of glass-forming melts and properties of glasses, the chemical composition of which is limited by the following content of components (mol.\%): $\mathrm{SrO} 30-80, \mathrm{~B}_{2} \mathrm{O}_{3}$ 10-60, $\mathrm{SiO}_{2}$ 10-60, and $\mathrm{Al}_{2} \mathrm{O}_{3} 0-10$. We showed that during synthesis of glasses in the corundum crucible during 60 minutes at the temperature of $1350^{\circ} \mathrm{C}$ the region of glass formation in the system $\mathrm{SrO}-\mathrm{B}_{2} \mathrm{O}_{3}-\mathrm{SiO}_{2}$ is limited by the following content of components (mol.\%): $\mathrm{SrO} 30-60, \mathrm{~B}_{2} \mathrm{O}_{3} 10-60$, and $\mathrm{SiO}_{2} 10-50$. It was found that the introduction of $\mathrm{Al}_{2} \mathrm{O}_{3}$ into the composition of these glasses expands the region of glass formation towards the increase of $\mathrm{SiO}_{2}$ content in glass up to $60 \mathrm{~mol} . \%$. Experimentally established values of experimental glass properties are within the following limits: coefficient of linear

Table 2

Values of additive coefficients $\left(v_{i}\right)$, their standard deviations $\left(S_{v}\right)$ and results of statistical analysis of calculation formulas

\begin{tabular}{|c|c|c|c|c|c|c|c|}
\hline \multirow{2}{*}{ Properties } & \multicolumn{4}{|c|}{ Values of $v_{i} \pm S_{v}$ for respective oxides } & \multirow{2}{*}{$\mathrm{R}$} & \multirow{2}{*}{$\mathrm{S}_{\mathrm{res}}^{2}$} & \multirow{2}{*}{$\mathrm{S}_{\mathrm{y}}^{2}$} \\
\hline & $\mathrm{SrO}$ & $\mathrm{B}_{2} \mathrm{O}_{3}$ & $\mathrm{SiO}_{2}$ & $\mathrm{Al}_{2} \mathrm{O}_{3}$ & & & \\
\hline CTE, $\alpha_{i} \cdot 10^{7}, \mathrm{~K}^{-1}$ & $164 \pm 3$ & $22 \pm 3$ & $52 \pm 3$ & $22 \pm 10$ & 0.99 & 7.23 & 209 \\
\hline Glass transition temperature, $\left(\mathrm{t}_{\mathrm{g}}\right)_{\mathrm{i}},{ }^{0} \mathrm{C}$ & $601 \pm 7$ & $538 \pm 7$ & $727 \pm 8$ & $571 \pm 25$ & 0.99 & 46 & 619 \\
\hline Dilatometric softening temperature, $\left(\mathrm{t}_{\mathrm{d}}\right)_{\mathrm{i}},{ }^{0} \mathrm{C}$ & $645 \pm 6$ & $531 \pm 5$ & $762 \pm 6$ & $698 \pm 20$ & 0.99 & 28 & 896 \\
\hline Volume resistivity, $\lg \rho_{\mathrm{i}}, \mathrm{Ohm} \cdot \mathrm{cm}$ & $15.2 \pm 0.3$ & $10.2 \pm 0.3$ & $12.2 \pm 0.3$ & $17.9 \pm 0.9$ & 0.99 & 0.08 & 0.37 \\
\hline Density, $\mathrm{d}_{\mathrm{i}}, \mathrm{g} / \mathrm{cm}^{3}$ & $4.45 \pm 0.06$ & $2.01 \pm 0.06$ & $2.87 \pm 0.07$ & $2.17 \pm 0.22$ & 0.99 & 0.003 & 0.06 \\
\hline
\end{tabular}


thermal expansion of $(67-118) \cdot 10^{-7} \mathrm{~K}^{-1}$; glass transition temperature of $570-660^{\circ} \mathrm{C}$; dilatometric softening point of $580-700^{\circ} \mathrm{C}$; and density of $2.62-$ $3.71 \mathrm{~g} / \mathrm{cm}^{3}$. At the temperature of $150^{\circ} \mathrm{C}$, the volume resistivity of glasses is in the range of $10^{12}-10^{14}$ $\mathrm{Ohm} Y \mathrm{~cm}$. Generalization of the dependences of glass properties on their chemical composition was carried out with the use of additive formula, for which the partial contributions of oxides to the values of the corresponding properties were determined by experimental and statistical methods. The established patterns of influence of the components and conditions of glass formation on the physical and chemical characteristics of glasses in the system $\mathrm{SrO}-$ $\mathrm{Al}_{2} \mathrm{O}_{3}-\mathrm{B}_{2} \mathrm{O}_{3}-\mathrm{SiO}_{2}$ may serve as an experimental base for designing of new materials with a complex of specified properties to solve the problems of their practical use.

\section{Acknowledgements}

This work was supported by the Ministry of Education and Science of Ukraine (project no. 0120U101969).

\section{REFERENCES}

1. Judd-Ofelt itemization and influence of energy transfer on $\mathrm{Sm}^{3+}$ ions activated $\mathrm{B}_{2} \mathrm{O}_{3}-\mathrm{ZnF}_{2}-\mathrm{SrO}-\mathrm{SiO}_{2}$ glasses for orangered emitting devices / Ravina, Naveen, Sheetal, Kumar V., Dahiya S., Deopa N., Punia R., Rao A.S. // J. Lumin. - 2021. - Vol.229. - P.117651.

2. Fluorescence spectroscopic studies of $\mathrm{Mn}^{2+}$ ions in $\mathrm{SrO}-\mathrm{Al}_{2} \mathrm{O}_{3}-\mathrm{B}_{2} \mathrm{O}_{3}-\mathrm{SiO}_{2}$ glass system / Rupesh Kumar A., Rao T.G.V.M., Veeraiah N., Rami Reddy M. // Opt. Mater. 2013. - Vol.35. - No. 3. - P.402-406.

3. Tuning the interfacial reaction between $\mathrm{CaO}-\mathrm{SrO}-\mathrm{Al}_{2} \mathrm{O}_{3}-\mathrm{B}_{2} \mathrm{O}_{3}-\mathrm{SiO}_{2}$ sealing glass-ceramics and Cr-containing interconnect: crystalline structure vs. glass structure / Chen J., Yang H., Chadeyron R., Tang D., Zhang T. // J. Eur. Ceram. Soc. - 2014. - Vol.34. - No. 8. - P.1989-1996.

4. Strontium borate glass: potential biomaterial for bone regeneration / Pan H.B., Zhao X.L., Zhang X., Zhang K.B., Li L.C., Li Z.Y., Lam W.M., Lu W.W., Wang D.P., Huang W.H., Lin K.L., Chang J. // J. R. Soc. Interface. - 2010. - Vol.7. P.1025-1031.

5. Influence of strontium on structure, bioactivity and corrosion behaviour of $\mathrm{B}_{2} \mathrm{O}_{3}-\mathrm{SiO}_{2}-\mathrm{Na}_{2} \mathrm{O}-\mathrm{CaO}$ glassesinvestigation by spectroscopic methods / Jagan Mohini G., Krishnamacharyulu N., Baskaran G.S., Rao C.S., Kumar V.R., Veeraiah N. // Opt. Mater. - 2018. - Vol.84. - P.292-300.

6. Patterns in the synthesis processes, the microstructure and properties of strontium-anorthite ceramics modified by glass of spodumene composition / Zaichuk O., Amelina A., Hordieiev Y., Kalishenko Y., Sribniak N., Halushka S., Borodai D., Borodai A.
// East.-Eur. J. Enterprise Technol. - 2020. - Vol.108. - No. 6. - P.15-26.

7. Appen A.A. Khimiya stekla. Leningrad: Khimiya. - 1974. $352 \mathrm{p}$.

8. Hordieiev Yu.S., Karasik E.V., Amelina A.A. Properties of glasses in the system $\mathrm{BaO}-\mathrm{B}_{2} \mathrm{O}_{3}-\mathrm{SiO}_{2}-\mathrm{xAl}_{2} \mathrm{O}_{3}(\mathrm{x}=0 ; 5$; 10 mol.\%) // Voprosy Khimii i Khimicheskoi Tekhnologii. 2021. - No. 3. - P.83-89.

9. Hsiang H.I., Chen C.C., Yang S.Y. Structure, crystallization, and dielectric properties of the $\mathrm{Al}_{2} \mathrm{O}_{3}$ filled $\mathrm{CaO}-\mathrm{B}_{2} \mathrm{O}_{3}-\mathrm{SiO}_{2}-\mathrm{Al}_{2} \mathrm{O}_{3}$ glass composites for $\mathrm{LTCC}$ applications // Jpn. J. Appl. Phys. - 2019. - Vol.58. - No. 9. - Art. No. 091010.

10. Effect of $\mathrm{Al}_{2} \mathrm{O}_{3}$ content on $\mathrm{BaO}-\mathrm{Al}_{2} \mathrm{O}_{3}-\mathrm{B}_{2} \mathrm{O}_{3}-\mathrm{SiO}_{2}$ glass sealant for solid oxide fuel cell / Sun T., Xiao H., Guo W., Hong X. // Ceram. Int. - 2010. - Vol.36. - No. 2. - P.821-826.

11. Glass formation region and order of formation of crystalline phases in the $\mathrm{SrO}-\mathrm{B}_{2} \mathrm{O}_{3}-\mathrm{SiO}_{2}$ system / Tyurnina N.G., Belousova O.L., Domanskii A.I., Doronina L.A., Ugolkov V.L. // Glass Phys. Chem. - 2010. - Vol.36. - P.294-303.

12. Glass powders with a high content of calcium oxide: a step towards a «green» universal biocide / Moya J.S., EstebanTejeda L., Pecharroman C., Mello-Castanho S.R., Da Silva A.C., Malpartida F. // Adv. Eng. Mater. - 2011. - Vol.13. - No. 6. P.B256-B260.

13. Goleus V.I., Hordieiev Yu.S. Calculation of optical constants of glasses in the $\mathrm{PbO}-\mathrm{B}_{2} \mathrm{O}_{3}-\mathrm{SiO}_{2}-\mathrm{GeO}_{2}$ oxide system // Voprosy Khimii i Khimicheskoi Tekhnologii. - 2018. No. 5. - P.92-96.

14. Karasik E.V., Hordieiev Yu.S. Calculation of thermal expansion, glass transition temperature and glass density in the system $\mathrm{RO}-\mathrm{Al}_{2} \mathrm{O}_{3}-\mathrm{B}_{2} \mathrm{O}_{3}-\mathrm{SiO}_{2}$ (where $\mathrm{RO}=\mathrm{BaO}, \mathrm{SrO}, \mathrm{CaO}$, $\mathrm{MgO}, \mathrm{ZnO}) / /$ Voprosy Khimii i Khimicheskoi Tekhnologii. 2020. - No. 6. - P.69-74.

Received 11.05.2021

\section{СКЛОУТВОРЕННЯ ТА ВЛАСТИВОСТІ СТЕКОЛ В \\ СИСТЕМI $\mathrm{SrO}-\mathrm{B}_{2} \mathrm{O}_{3}-\mathrm{SiO}_{2}-\mathrm{xAl}_{2} \mathrm{O}_{3}(\mathrm{x}=0 ; 10$ МОЛ.\%)}

\section{Ю.С. Гордєєв, О.А. Амеліна}

У роботі показано перспективність застосування системи $\mathrm{SrO}-\mathrm{Al}_{2} \mathrm{O}_{3}-\mathrm{B}_{2} \mathrm{O}_{3}-\mathrm{SiO}_{2}$, як основи для синтезу нових склоподібних і склокерамічних матеріалів, що широко використовують як електроізоляційні та жаростійкі покриття, для герметизації твердооксидних паливних елементів, а також у виробництві термостійких матеріалів. Експериментально встановлено умови склоутворення, ділянки склоутворюючих розплавів і властивості стекол, хімічний склад яких обмежений наступним вмістом компонентів (мол.\%): $\mathrm{SrO}$ $30-80, \mathrm{~B}_{2} \mathrm{O}_{3} 10-60, \mathrm{SiO}_{2} 10-60, \mathrm{Al}_{2} \mathrm{O}_{3} 0-10$. Показано, що при синтезі стекол в корундовому тиглі при температурі $1350^{\circ} \mathrm{C}$ регіон склоутворення в системі $\mathrm{SrO}-\mathrm{B}_{2} \mathrm{O}_{3}-\mathrm{SiO}_{2}$ обмежений вмістом компонентів (мол.\%): $\mathrm{SrO} 30-60, \mathrm{~B}_{2} \mathrm{O}_{3} 10-$ $60, \mathrm{SiO}_{2}$ 10-50. Встановлено, що введення до складу цих стекол $\mathrm{Al}_{2} \mathrm{O}_{3}$ розширює інтервал склоутворення в напрямі збільшення в склі вмісту $\mathrm{SiO}_{2}$ до 60 мол.\%. Експерименталь- 
но встановлені значення властивостей дослідних стекол знаходяться в наступних межах: температурний коефіцієнт лінійного розширення $(67-118) \cdot 10^{-7} \mathrm{~K}^{-1}$; температура склування $570-660^{\circ} \mathrm{C}$; дилатометрична температура розм'якшення

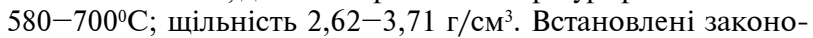
мірності впливу компонентів і умов склоутворення на фізико-хімічні характеристики стекол можуть слугувати експериментальною базою для проектування нових матеріалів 3 комплексом заданих показників властивостей, що вирішує задачі їх практичного використання.

Ключові слова: скло, склоутворення, теплове розширення, температура склування, питомий об'ємний опір.

\section{GLASS FORMATION AND PROPERTIES OF GLASSES IN THE SYSTEM SrO- $\mathrm{B}_{2} \mathrm{O}_{3}-\mathrm{SiO}_{2}-\mathrm{xAl}_{2} \mathrm{O}_{3}(\mathrm{x}=0 ; 10 \mathrm{MOL} . \%)$}

\section{Yu.S. Hordieiev ", A.A. Amelina}

Ukrainian State University of Chemical Technology, Dnipro, Ukraine

*e-mail: yuriihordieiev@gmail.com

The paper shows the prospects of the system $\mathrm{SrO}-\mathrm{Al}_{2} \mathrm{O}_{3}-\mathrm{B}_{2} \mathrm{O}_{3}-\mathrm{SiO}_{2}$ as a basis for the synthesis of new vitreous and glass-ceramic materials, which are widely used as electrical insulated and high-temperature coatings, for sealing of solid oxide fuel cells, and in the production of heat resistant materials. We experimentally established the conditions of glass formation, regions of glass-forming melts and properties of glasses, the chemical composition of which is limited by the following content of components (mol.\%): $\mathrm{SrO} 30-80, \mathrm{~B}_{2} \mathrm{O}_{3} 10-60, \mathrm{SiO}_{2} 10-60$, and $\mathrm{Al}_{2} \mathrm{O}_{3} 0-10$. It is shown that during the synthesis of glasses in the corundum crucible at the temperature of $1350^{\circ} \mathrm{C}$ the region of glass formation in the system $\mathrm{SrO}-\mathrm{B}_{2} \mathrm{O}_{3}-\mathrm{SiO}_{2}$ is limited by the following content of components (mol.\%): $\mathrm{SrO} 30-60, \mathrm{~B}_{2} \mathrm{O}_{3}$ $10-60$, and $\mathrm{SiO}_{2}$ 10-50. It is found that the introduction of $\mathrm{Al}_{2} \mathrm{O}_{3}$ to the composition of these glasses expands the region of glass formation towards increase of the $\mathrm{SiO}_{2}$ content in the glass up to $60 \mathrm{~mol} . \%$. Experimentally determined values of glass properties are within the following limits: coefficient of linear thermal expansion $(67-118) \cdot 10^{-7} \mathrm{~K}^{-1}$; glass transition temperature $570-$ $660^{\circ} \mathrm{C}$; dilatometric softening point $580-700^{\circ} \mathrm{C}$; and density $2.62-$ $3.71 \mathrm{~g} \mathrm{~cm}^{-3}$. The established patterns of influence of the components and conditions of glass formation on the physical and chemical characteristics of glasses may serve as an experimental basis for designing of new materials with a complex of specified properties, which allows solving the problems of their practical use.

Keywords: glass; glass formation; thermal expansion; glass transition temperature; volume resistivity.

\section{REFERENCES}

1. Ravina, Naveen, Sheetal, Kumar V, Dahiya S, Deopa $\mathrm{N}$, et al. Judd-Ofelt itemization and influence of energy transfer on $\mathrm{Sm}^{3+}$ ions activated $\mathrm{B}_{2} \mathrm{O}_{3}-\mathrm{ZnF}_{2}-\mathrm{SrO}-\mathrm{SiO}_{2}$ glasses for orangered emitting devices. J Lumin. 2021; 229: 117651.

doi: 10.1016/j.jlumin.2020.117651.

2. Kumar AR, Rao TGVM, Veeraiah N, Reddy MR. Fluorescence spectroscopic studies of $\mathrm{Mn}^{2+}$ ions in $\mathrm{SrO}-\mathrm{Al}_{2} \mathrm{O}_{3}-\mathrm{B}_{2} \mathrm{O}_{3}-\mathrm{SiO}_{2}$ glass system. Opt Mater. 2013; 35: 402406. doi: $10.1016 /$ j.optmat.2012.09.008.
3. Chen J, Yang H, Chadeyron R, Tang D, Zhang T. Tuning the interfacial reaction between $\mathrm{CaO}-\mathrm{SrO}-\mathrm{Al}_{2} \mathrm{O}_{3}-\mathrm{B}_{2} \mathrm{O}_{3}-\mathrm{SiO}_{2}$ sealing glass - ceramics and $\mathrm{Cr}$-containing interconnect: crystalline structure vs. glass structure. J Eur Ceram Soc. 2014; 34: 19891996. doi: 10.1016/j.jeurceramsoc.2014.01.023.

4. Pan HB, Zhao XL, Zhang X, Zhang KB, Li LC, Li ZY, et al. Strontium borate glass: potential biomaterial for bone regeneration. J R Soc Interface. 2010; 7: 1025-1031. doi: 10.1098/rsif.2009.0504.

5. Mohini GJ, Krishnamacharyulu N, Baskaran GS, Rao CS, Kumar VR, Veeraiah N. Influence of strontium on structure, bioactivity and corrosion behaviour of $\mathrm{B}_{2} \mathrm{O}_{3}-\mathrm{SiO}_{2}-\mathrm{Na}_{2} \mathrm{O}-\mathrm{CaO}$ glasses-investigation by spectroscopic methods. Opt Mater. 2018; 84: 292-300. doi: 10.1016/j.optmat.2018.07.024.

6. Zaichuk O, Amelina A, Hordieiev Y, Kalishenko Y, Sribniak N, Halushka S, et al. Patterns in the synthesis processes, the microstructure and properties of strontium-anorthite ceramics modified by glass of spodumene composition. East Eur J Enterprise Technol. 2020; 108(6): 15-26.

doi: 10.15587/1729-4061.2020.216754.

7. Appen AA. Kimiya stekla [Chemistry of glass]. Leningrad: Khimiya; 1974. 352 p. (in Russian).

8. Hordieiev YuS, Karasik EV, Amelina AA. Properties of glasses in the system $\mathrm{BaO}-\mathrm{B}_{2} \mathrm{O}_{3}-\mathrm{SiO}_{2}-\mathrm{xAl}_{2} \mathrm{O}_{3}(\mathrm{x}=0 ; 5 ; 10$ mol.\%). Voprosy Khimii i Khimicheskoi Tekhnologii. 2021; (3): 83-89. doi: 10.32434/0321-4095-2021-136-3-83-89.

9. Hsiang HI, Chen CC, Yang SY. Structure, crystallization, and dielectric properties of the $\mathrm{Al}_{2} \mathrm{O}_{3}$ filled $\mathrm{CaO}-\mathrm{B}_{2} \mathrm{O}_{3}-\mathrm{SiO}_{2}-\mathrm{Al}_{2} \mathrm{O}_{3}$ glass composites for LTCC applications. Jpn J Appl Phys. 2019; 58(9): 091010. doi: 10.7567/1347-4065/ab3cc5.

10. Sun $\mathrm{T}$, Xiao $\mathrm{H}$, Guo W, Hong X. Effect of $\mathrm{Al}_{2} \mathrm{O}_{3}$ content on $\mathrm{BaO}-\mathrm{Al}_{2} \mathrm{O}_{3}-\mathrm{B}_{2} \mathrm{O}_{3}-\mathrm{SiO}_{2}$ glass sealant for solid oxide fuel cell. Ceram Int. 2010; 36: 821-826. doi: $10.1016 / j$.ceramint.2009.09.045.

11. Tyurnina NG, Belousova OL, Domanskii AI, Doronina LA, Ugolkov VL. Glass formation region and order of formation of crystalline phases in the $\mathrm{SrO}-\mathrm{B}_{2} \mathrm{O}_{3}-\mathrm{SiO}_{2}$ system. Glass Phys Chem. 2010; 36: 294-303. doi: 10.1134/S1087659610030041.

12. Moya JS, Esteban-Tejeda L, Pecharroman C, MelloCastanho SR, Da Silva AC, Malpartida F. Glass powders with a high content of calcium oxide: a step towards a «green» universal biocide. Adv Eng Mater. 2011; 13: B256-B260. doi: 10.1002/adem.201080133.

13. Goleus VI, Hordieiev YS. Calculation of optical constants of glasses in the $\mathrm{PbO}-\mathrm{B}_{2} \mathrm{O}_{3}-\mathrm{SiO}_{2}-\mathrm{GeO}_{2}$ oxide system. Voprosy Khimii i Khimicheskoi Tekhnologii. 2018; (5): 92-96.

14. Karasik EV, Hordieiev YuS. Calculation of thermal expansion, glass transition temperature and glass density in the system $\mathrm{RO}-\mathrm{Al}_{2} \mathrm{O}_{3}-\mathrm{B}_{2} \mathrm{O}_{3}-\mathrm{SiO}_{2}$ (where $\mathrm{RO}=\mathrm{BaO}, \mathrm{SrO}, \mathrm{CaO}$, $\mathrm{MgO}, \mathrm{ZnO}$ ). Voprosy Khimii i Khimicheskoi Tekhnologii. 2020; (6): 69-74. doi: 10.32434/0321-4095-2020-133-6-69-74. 